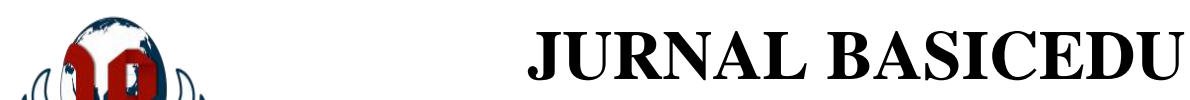

Volume 5 Nomor 4 Tahun 2021 Halaman 2171 - 2180

Research \& Learning in Elementary Education

https://jbasic.org/index.php/basicedu

\title{
Pembelajaran Tematik Terpadu menggunakan Model Problem Based Learning di Sekolah Dasar
}

\author{
Firda Khairati Amris ${ }^{1 凶}$, Desyandri ${ }^{2}$ \\ Pendidikan Dasar, Universitas Negeri Padang, Indonesia ${ }^{1,2}$ \\ E-mail: firdakhairati@gmail.com ${ }^{1}$, desyandri@ fip.unp.ac.id ${ }^{2}$
}

\begin{abstract}
Abstrak
Pengamatan ini bermanfaat dalam menjelaskan pelaksanaan metode belajar mengajar dalam pembelajaran terpadu sekolah dasar. Peserta didik tidak berpartisipasi pada bidang ini karena pelajaran ini selalu dimotivasi oleh pembelajaran teacher-centric (teacher-centric), guru tidak memberikan pengalaman langsung, dan pembelajaran tampak tidak fleksibel. Pelaksanan metode PBL yaitu model belajar mengajar yang memaparkan siswa pada permasalahan konkrit dalam kehidupan saat belajar. Permasalah disajikan untuk siswa lalu mereka memahami konsep dan materi yang berhubungan terkait masalah tersebut. Oleh karena itu, untuk memecahkan masalah ini, peserta didik menemukan bahwa peserta didik memerlukan wawasan baru untuk belajar bagaimana mengatasi permasalahan yang disajikan pendidik. Oleh karena itu, model ini berpusat pada siswa karena sangat penting untuk mengintegrasikan ekstrem ke dalam proses pembelajaran. Penelitian ini menggunakan metode literature review (pencarian dokumen) untuk menyempurnakan analisis dari berbagai sumber yang digunakan. Artikel dicari menggunakan jurnal online di Google Scholar sebagai data hasil penelitian nya. Kata kunci yang dapat di manfaatkan dalam pengamatan jurnal tersebut yaitu proses belajar mengajar berbasis masalah, model belajar mengajar tematik terpadu. Hasil analisis artikel pelaksanaan metode pelajaran berbasis masalah dikatakan efektif dalam menerapkan pembelajaran terpadu tematik di tingkat dasar.
\end{abstract}

Kata Kunci : Model Pembelajaran Problem Based Learning, Tematik Terpadu.

\begin{abstract}
This is useful in explaining the implementation of teaching and learning methods in integrated learning in elementary schools. Students do not participate in this field because these lessons are always motivated by teacher-centric (teacher-centric) learning, teachers do not provide direct experience, and learning seems inflexible. The implementation of the PBL method is a teaching and learning model that describes concrete problems in life while learning. Problems are presented to students and then understand the concepts and materials related to the problem. Therefore, to solve this problem, students find that students need new experiences to learn how to solve problems presented by educators. Therefore, this model is student-centered because it is very important to integrate extremes into the learning process. This study uses the literature review method (document search) to complete the analysis of the various sources used. Articles searched using online journals on Google Scholar as research data. Keywords that can be used in the observation of the journal are problem-based teaching and learning processes, integrated thematic teaching and learning models. The results of the analysis of the implementation of effective problem-based learning in implementing thematic integrated learning at the elementary level.
\end{abstract}

Keywords: Problem Based Learning Model, Integrated Thematic

Copyright (c) 2021 Firda Khairati Amris, Desyandri

Corresponding author :

Email : firdakhairati@gmail.com

DOI : $\quad$ https://doi.org/10.31004/basicedu.v5i4.1170

ISSN 2580-3735 (Media Cetak)

ISSN 2580-1147 (Media Online)

Jurnal Basicedu Vol 5 No 4 Tahun 2021

p-ISSN 2580-3735 e-ISSN 2580-1147 
2172 Pembelajaran Tematik Terpadu menggunakan Model Problem Based Learning di Sekolah Dasar Firda Khairati Amris, Desyandri

DOI: https://doi.org/10.31004/basicedu.v5i4.1170

\section{PENDAHULUAN}

Kurikulum yang digunakan di tingkat SD adalah kurikulum 2013 yang menggunakan pembelajaran terpadu berorientasi mata pembelajaran. Pelaksanaan proses belajar mengajar tematik yaitu model belajar mengajar terpadu yang menerapkan tema untuk menghubungkan topik yang berbeda dan menyuguhkan pengalaman yang berkesan kepada siswa. Pembelajaran terpadu adalah pendekatan pembelajaran yang mengintegrasikan secara mulus materi yang berbeda dan beberapa topik terkait untuk memberikan siswa pengalaman belajar yang bermakna. Menurut (Indriyani 2019) Ia mengatakan, perubahan yang dilakukan pada kurikulum 2013 selama ini merupakan upaya untuk meningkatkan penyampaian proses pendidikan. Keterampilan Bertujuan untuk memperkuat dan menyeimbangkan sikap, keterampilan dan pengetahuan. Senada dengan pendapat (M. Desyandri, Mansurdin, and Fahmi 2019) bahwa dalam sirkulasi industri 4.0 pelajaran serta pengajaran di Indonesia telah memperkenalkan program baru, program Kementerian Pendidikan dan Kebudayaan 2013. Sekelompok mata pembelajaran diintegrasikan untuk memberikan dampak waktu di dalam kelas, tetapi di sisi lain, meskipun kurikulum merupakan faktor kuat pada pelaksanaan pendidikan di sekolah, beberapa mata pelajaran diajarkan dalam pendampingan, sehingga lebih efektif setiap hari. berkurang. Kurikulum Tingkat Satuan Pendidikan (KTSP) merupakan kurikulum tahun 2013 yang dikembangkan. Senada (D. Desyandri and Vernanda 2017) Disebutkan bahwa kurikulum Sekolah Dasar (SD) 2013 terintegrasi secara tematik. Pelaksanaan belajar mengajar lebih memfokuskan pada ranah mental, kemasyarakatan, wawasanan serta keahlian dengan mengkaji serta mengevaluasi portofolio lebih lanjut. Kemudian (Julia Purnama Sari; Yunisrul; Desyandri 2018) Belajar tentang suatu mata pelajaran dikatakan sebagai pembelajaran yang terjadi melalui mata pelajaran sebagai satu kesatuan yang utuh, karena untuk memahami gejala dan konsep membutuhkan pusat perhatian.

Pembelajaran tema terpadu adalah pembelajaran yang dapat diberikan kepada siswa pengalaman yang bermakna, dan pembelajaran tema terpadu berfokus untuk siswa dan pengalaman langsung juga diberikan, sehingga siswa diteliti secara mendalam, bermakna dan memiliki berbagai konsep asli sendiri. Dari berbagai konsep. Bagi siswa, fleksibel beradaptasi dengan minat dan kebutuhan mereka, serta menerapkan prinsipprinsip pembelajaran berbasis bermain untuk mencapai tujuan pembelajaran tematik terpadu yang menghasilkan siswa aktif. Pembelajaran tematik terpadu memungkinkan siswa menggali dan mengolah informasi yang diperoleh karena pembelajaran bersifat student-centric, sedangkan guru hanya mendukung selama proses pembelajaran, sehingga siswa proaktif dalam pembelajaran (Mesyta Putri Ayu 2020). Pendapat ahli Prananda, (2020) menjelaskan bahwa kebutuhan belajar terpadu dalam prosesnya harus secara aktif, serta jujur mencari, menggali dan menemukan konsep dan prinsip.

Berdasarkan beberapa pendapat tersebut, Kegiatan pembelajaran tematik terpadu berpusat pada siswa, hanya dipimpin oleh guru, sedangkan kegiatan menuntut siswa untuk aktif belajar. Ada banyak faktor dalam proses pembelajaran yang mempengaruhi keberhasilan siswa, yaitu metode dan model pembelajaran. Guru yang telah menyesuaikan materinya dan memilah metode pelajaran yang sesuai, berupaya menarik perhatian siswa yang ikutserta dalam kegiatan belajar mengajar, menggali berbagai informasi, dan mengembangkan keterampilan untuk mencapai tujuan pembelajarannya. (Maharani and Hardini 2017). Artinya guru sebagai pendidik memegang peranan penting dalam mencapai tujuan pembelajarannya secara memadai. Hal ini dapat dilakukan dengan menciptakan proses pembelajaran yang efektif (Ramadhani 2021)

Namun pada kenyataannya, itu tidak seperti yang Anda harapkan. Menurut penelitian-penelitian sebelumnya masih banyak ditemukan permasalahan guru dan penggunaan metode kuis oleh sebagian besar guru dan tanya jawab saat pembelajaran. Saat ini telah banyak dikemukakan model serta metode yang memungkinkan proses belajar mengajar pada peserta didik berperan aktif, namun guru masih ragu dalam proses pembelajaran untuk diterapkan dan tujuan pembelajarannya secara optimal. Aktivitas siswa dalam interaksi sangat terlihat pembelajaran yang kurang menegangkan. Komunikasi antar siswa juga cenderung 
2173 Pembelajaran Tematik Terpadu menggunakan Model Problem Based Learning di Sekolah Dasar Firda Khairati Amris, Desyandri

DOI: https://doi.org/10.31004/basicedu.v5i4.1170

berada di luar materi ajar, daripada berfokus pada pemecahan masalah akademik. Akibatnya, tugas biasanya tidak selesai dalam waktu yang ditentukan. Menghadapi situasi tersebut, tingkat kerjasama siswa masih rendah, terutama dalam kelompok. Oleh karena itu, guru tidak mengajarkan siswa untuk aktif mengembangkan dan mempresentasikan hasil kerjanya, guru tidak mengedepankan kemampuan siswa dalam memecahkan masalah nyata di sekitar. Di sisi lain, dalam pelaksanaan proses pembelajaran selalu ada pemisahan yang jelas antar mata pelajaran. Guru berpedoman pada buku guru dan siswa tanpa melengkapi sumber lain seperti materi dari buku.

Menghadapi permasalahan tersebut, penerapan pembelajaran tematik terpadu menjadi penting. Salah satu cara agar pembelajaran berbasis mata pelajaran terpadu lebih efektif adalah metode yang digunakan pendidik dalam memilih serta menerapkan metode pelajaran yang sesuai dengan bahan ajar. Menurut (Efendi and Wardani 2021) metode pelajaran yaitu bentuk penyiapan dokumen yang dimanfaatkan oleh pendidik sebagai aturan dasar pada pelaksanaan kegiatan pembelajaran. Metode pelajaran yang dapat diterapkan yaitu metode pembelajaran PBL. Menurut (Saputra 2016) metode pembelajaran PBL ialah metode palajaran dengan mengikutsertakan peserta didik dalam pemecahan masalah sehingga mereka dapat mengalami secara langsung proses penyelidikan konsep yang mereka pelajari. Agar siswa dapat berpikir kritis dalam memecahkan masalah. Selain itu (Febriani 2020) Problem Based Learning yaitu belajar yang melibatkan suatu permasalahan terbuka tidak terstruktur dunia nyata sebagai konteks di mana siswa dapat mengembangkan keterampilan pemecahan masalah dan membangun pengetahuan siswa baru serta berpikir kritis. PBL mengaktifkan pembelajaran siswa dengan masalah kehidupan nyata sebelum siswa mengetahui konsep formal. Sedangkan menurut (Handayani and Muhammadi 2020) Metode pelajaran PBL yaitu suatu model supaya menginspirasi untuk terlibat aktif pada pelaksanan belajar mengajar yang dilakukan oleh siswa dengan menyajikan masalah dan mengajukan pertanyaan untuk membantu mereka memperluas pengetahuan mereka.

Pada dasarnya metode pelajaran PBL yaitu kegiatan belajar mengajar yang menuntut untuk peserta didik memikirkan serta masalah nyata yang dipecahkan. (Wulandari 2020) Proses pembelajaran pembelajaran berbasis masalah diawali oleh identifikasi/penyajian masalah, pengumpulan data, pembuatan hipotesis antara berdasarkan diskusi, pelaksanaan inkuiri yang dipimpin siswa, presentasi publik/karya di depan kelas dan evaluasi. penyelesaian masalah. Berdasarkan hal tersebut dapat disimpulkan bahwa peran guru dalam PBL hanya peran fasilitator dan siswa lebih aktif belajar. Model pembelajaran berbasis proyek (PBL) merupakan solusi masalah pembelajaran tematik terpadu yang dapat diterapkan pada guru sekolah.

Berdasarkan penjelasan tersebut, pengamatan itu berfokus dalam menjelaskan metode PBL pada pembelajaran terpadu di sekolah dasar. penulisan ini perlu memberikan manfaat untuk dijadikan referensi oleh pendidik pada kegiatan belajar mengajar, terutama konten yang berhubungan pada metode pelajaran PBL dalam pengajaran terpadu berdasarkan topik di sekolah dasar.

\section{METODE}

Dalam artikel ini metode yang digunakan termasuk pencarian bibliografi dengan tinjauan bibliografi untuk meningkatkan analisis dari berbagai sumber yang digunakan. Tinjauan pustaka dalam risalah ini menjadi dasar dari rencana penulisan pertama dan sumber bahan penulisan. Tinjauan bibliografi adalah studi yang didasarkan pada studi tertulis yang mencakup Hasil penelitian, dipublikasikan dan tidak dipublikasikan.

Pengumpulan data penelitian dilakukan oleh peneliti yaitu artikel jurnal online menggunakan Google Scholar yang dicari. Keyword yang peneliti gunakan saat meneliti artikel adalah "Motode pelajaran Problem Based Learning dan Tematik Terpadu." Hasil penelitian ditinjau serta dianalisis menggunakan pemindaian konten, dirangkum dan ditampilkan dalam laporan penelitian. 
2174 Pembelajaran Tematik Terpadu menggunakan Model Problem Based Learning di Sekolah Dasar Firda Khairati Amris, Desyandri

DOI: https://doi.org/10.31004/basicedu.v5i4.1170

\section{HASIL DAN PEMBAHASAN}

\section{Metode pembelajaran Problem Based Learning}

Metode pelajaran berbentuk masalah merupakan metode pelajaran yang menerapkan permasalahan konkrit seperti lingkungan peserta didik dalam berlatih memecahkan permasalahan, kemampuan dalam memecahkan permasalahan dan mendapatkan wawasan serta gambaran bahan ajar. Menurut (Rahayu 2016) pelajaran Problem Based Learning ialah tahapan pelajaran yang memaksimalkan kompetensi peserta didik secara memadai yang sistematis melalui kerja kelompok. Hal ini memungkinkan siswa untuk terus memperkuat, meningkatkan, menguji, dan mengembangkan keterampilan berpikir mereka dengan cara yang menargetkan masalah kehidupan nyata. Ketika mereka mencoba memecahkan masalah yang muncul karena perkembangan intelektual siswa terjadi ketika individu menghadapi pengalaman baru dan sulit. Kemudian menurut (Kristin 2018) Dalam pembelajaran, siswa diorientasikan pada kerja kelompok untuk memecahkan masalah yang dibahas secara sistematis biasanya melibatkan siswa belajar melalui masalah kehidupan nyata yang terkait dengan kehidupan nyata. Siswa kemudian didorong menemukan kasus serta data yang mereka butuhkan dibeberapa referensi hingga mereka dapat memecahkan permasalahan tersebut. Tujuan akhirnya adalah memungkinkan siswa untuk menemukan solusi atas masalah mereka, untuk mendekati masalah secara kritis dan sistematis yang dibahas, dan untuk menarik pemahaman mereka untuk menyimpulkan.

Pembelajaran problem based learning juga dikenal sebagai pembelajaran aktif karena siswa menemukan informasi sendiri dalam prosesnya. Hal ini dipertegas oleh (Ramadhani 2021) Siswa dilatih untuk menemukan informasi yang mereka butuhkan. Mereka diharapkan berperan aktif tidak untuk konsumen tetapi juga sebagai agen dalam penemuan pengetahuan. Model pembelajaran berbasis masalah disesuaikan dengan minat dan kebutuhan siswa, dalam kegiatan pembelajaran mengemukakan peserta didik supaya berpartisipasi pada pelaksanaan pelajaran secara langsung. Sejumlah temuan bergaya jurnal menjelaskan bahwa metode (PBL) yang dilaksanakan dalam pembelajaran berbasis mata pelajaran terpadu di sekolah dasar mampu mengembangkan kualitas prestasi peserta didik.

Metode pelajaran problem based learning mampu mendukung kinerja siswa dalam belajar. Guru harus mampu melaksanakan pembelajaran berbasis masalah dengan cara yang benar. Tahapan metode pelajaran PBL adalah: 1) mengarahkan siswa pada suatu permasalahan 2) membuat kelompok pembelajaran siswa, 3) melakukan penelitian individu serta kelompoknya, 4) menganalisis serta menyampaikan pekerjaan yang sedang berjalan. 5) Proses resolusi untuk menganalisis dan menilai masalah (Yelnosia and Taufik 2020). Metode pelajaran banyak direkomendasikan yaitu metode PBL karena kelebihan yang dimilikinya. (Vera and Astuti 2019) mengemukakan keuntungan dari metode PBL. Artinya, peserta didik mampu secara proaktif mengatasi permasalah, memperdalam pemahaman konsep, mengintegrasikan pengetahuan, merasakan manfaat belajar, memiliki aspirasi, menerima pendapat orang lain, dan berinteraksi dalam kelompok.

Pembelajaran yang dikemas sebagai suatu topik atas dasar isi beberapa mata pelajaran yang digabungkan atau terpadu ialah pembelajaran tematik terpadu. Topik adalah tempat atau cara untuk memperkenalkan konsep materi yang berbeda kepada seluruh siswa. Menurut (Mesyta Putri Ayu 2020) pelajaran tematik yaitu pelajaran dengan satu kesatuan tema dan pelaksanaan pelajaran dengan menggabungkan sebagian topik secara bersamaan menjadi satu pelajaran dengan tujuan pembelajaran pada siswa yang bermakna. Pelajaran tematik terpadu memiliki beberapa karakteristik yang menjadi ciri pembelajaran mata pelajaran terpadu itu sendiri. Menurut (Majid 2014) ciri-ciri pelajaran tematik terpadu yaitu: (a) pelajaran yang berpusat pada siswa atau siswa, (b) memberikan pengalaman langsung, (c) topik yang tidak jelas terfokus pada mata pelajaran: pemisahan, (d) pengenalan Menggunakan prinsip konsep pelajaran dari berbagai mata pelajaran, (e) fleksibilitas dan kemudahan koneksi dengan kehidupan sehari-hari siswa, (f) prinsip pembelajaran bermain dan menyenangkan adalah pelajaran.yang meningkatkan keterampilan siswa yang bermakna, peserta didik dilatih kemampuannya untuk menemukan konsep yang beragam, dipelajari dengan baik, bermakna, dan terbukti dengan sendirinya, dengan pembelajaran tematik 
2175 Pembelajaran Tematik Terpadu menggunakan Model Problem Based Learning di Sekolah Dasar Firda Khairati Amris, Desyandri

DOI: https://doi.org/10.31004/basicedu.v5i4.1170

terpadu akan banyak memberikan kelebihan. Menurut (Trianto 2009) kelebihan pembelajaran tematik terpadu yaitu: (1) Kegiatan dan pengalaman belajar siswa disesuaikan pada jenjang perkembangannya, (2) minat dan kebutuhannya sesuai dengan kegiatan yang dipilih, (3) Proses belajar merupakan praktik yang bermakna bagi siswa, Keterampilan berpikir siswa, yang mampu menopang hasil untuk jangka waktu yang lama, dikembangkan melalui proses pembelajaran terpadu. (5) Pelatihan dan pembelajaran praktis Tergantung pada lingkungan siswa, (6) keterampilan dikembangkan dalam jaringan sosial siswa.

\section{Analisis Model Problem Based Learning dalam penerapan Pelajaran Tematik Terpadu di Sekolah Dasar}

Sebagai temuan penelitian metode pelajaran problem based learning pada penerapan pelajaran terpadu tematik SD, peneliti memperoleh 20 artikel terkait berdasarkan sumber data sebelumnya. Data artikel diproses dengan menggabungkan dan menentukan hasil pencarian. Di bawah ini adalah hasil analisis yang peneliti peroleh dari 20 artikel terkait metode pelajaran berbasis masalah pada penerapan pelajaran tematik terpadu di sekolah dasar. Hasil penganatan (Dewi and Wardani 2019) mengembangkan bahwa Penerapan pembelajaran berbasis masalah adalah pelajaran tematik peserta didik Kelas II yang pelaksanaan pembelajaran berbasis masalah, menunjukkan banyaknya siswa yang mendapat KKM 90\% sesuai kriteria sebagai berikut: tematik yang saya jelaskan meningkatkan hasil, dapat meningkatkan kinerja dalam pembelajaran di kelas.

Hasil penelitian (Eliyasni, Anita, and Hanafi 2020) menjelaskan bahwa peningkatan RPP siklus I yang ditemui tercatat 84,38 dalam baik (B) dan peningkatan pada pertandingan pertama siklus 2 mencapai nilai 90,63 dalam baik (SB). Peningkatan juga terjadi pada Sangat Baik (SB) pada siklus II sebesar 96,87. Pelaksanaan proses pembelajaran didasarkan pada tahapan model pembelajaran berbasis masalah. Berdasarkan observasi menunjukkan bahwa pelaksanaan proses pembelajaran belum mencapai efisiensi yang maksimal dengan menggunakan lembar observasi guru dan siswa. Tabel tersebut menunjukkan bahwa persentase aspek ajaran siklus I pertemuan pertama adalah 78,57 dengan derajat baik (B) dan persentase sisi siswa 78,57 dengan derajat baik (B). Meningkat dalam tahap 1 Pertemuan 2. Artinya, lembar observasi guru mendapat nilai 89,28 untuk Ijazah Baik (SB), dan pihak siswa mendapat nilai 89,28 untuk nilai sangat baik (SB). Peningkatan juga terjadi pada siklus II. Dengan kata lain, nilai lembar observasi pada sisi pelajaran adalah 96, 2 yang merupakan prestasi akademik (SB) sangat baik, dan pada sisi siswa nilai 96, 2 yang merupakan kriteria sangat baik (SB).

Hasil penelitian (Yolanda 2018) menjelaskan bahwa selama periode pelaksanaan pada tahap 1 ke tahap 2, kegiatan pedagogik pendidik serta aktivitas belajar peserta didik meningkat. Peningkatan produksi dinyatakan sebagai persentase kenaikan dalam setiap siklus. Hasil penelitian (Reinita 2020) menjelaskan peningkatan rencana pelaksanaan pembelajaran (RPP). Predikat rata-rata baik pada siklus 1 lalu berkembang dalam tahap 2 yang memperoleh kategori amat bagus. Kinerja kegiatan pendidik pada tahap 1 rata-rata, hasilnya sudah cukup, serta peningkatan dalam tahap 2 sudah amat bagus. Dalam tahap 1 rata-rata pemerolehannya cukup serta pada tahap 2 meningkat amat baik sebagai kinerja aktivitas peserta didik. Dalam tahap 1 berada di atas rata-rata serta peningkatan dalam tahap 2 sudah amat bagus sebagai prestasi dalam pembelajaran. Maka dari itu, metode PBL terbukti dalam pelajaran mata pelajaran terpadu di sekolah dasar mampu menumbuhkan minat siswa.

Menurut (Setiyaningrum 2018) Penggunaan metode PBL dapat digunakan dalam pencapaian prestasi belajar peserta didik yang ditingkatkan serta kegiatan pembelajaran. Adanya peningkatan proporsi pencapaian proses pelajaran dan kegiatan peserta didik yang telah memperoleh KKM baik dalam tahap I maupun Siklus II pada hasil penelitiannya. Maka dari itu, pelajaran (PBL) menunjukkan bahwa hasil belajar dapat ditingkatkan, khususnya dengan isi tema 1 mata pelajaran kewarganegaraan dan IPS SD Negeri Salatiga. Hasil penelitian (Ramadani and Mansurdin 2020) menjelaskan bahwa Penerapan pembelajaran pada metode problem based learning siswa IV SDN 3 Aia Pacah dilakukan prosedural secara bertahap penerapan model PBL. Adalah peserta didik mengatasi permasalahan, mengatur pembelajaran siswa, menyiapkan dan mempresentasikan 
pekerjaan/laporan dan mengamati serta melakukan penilaian terhadap kegiatan pemecah masalah. Penerapan metode pelajaran berbasis masalah dalam proses pembelajaran semakin meningkat setiap siklusnya. Oleh karena itu, metode (PBL) mampu mengembangkan kegiatan belajar mengajar dengan SDN 3 Aia Pacah. Hasil penelitian (Krismayanti 2020) menjelaskan bahwa terdapat peningkatan hasil pelaksanaan rencana pembelajaran, pelaksanaan pembelajaran, dan penerapan pelajaran dalam topik terpadu yang memerlukan problem based learning (PBL). Ini diwakili oleh peningkatan siklus, Oleh karena itu, hal ini menunjukkan adanya perkembangan dalam kegiatan pelajaran terpadu tematik pada metode (PBL) di kelas V SD Negeri 20 Indarung Kota Padang.

Hasil penelitian (Handayani and Muhammadi 2020) menjelaskan bahwa pencapaian prestasi peserta didik yang dibelajarkan memerlukan metode PBL yang disampaikan dengan pengajaran tradisional dalam pelajaran terpadu tema Topik 8, Tema 3, Pembelajaran 3 dan V SDN 35 Parak Karakah Kecamatan Padang Timur. Ini bisa di tinjau dari pencapaian evaluasi yang signifikansi 5\% (kepercayaan 95\%), dimana terhitung $>$ tabel adalah , $3>2,037$. Nilai terhitung $>$ tabel merepresentasikan prestasi Pembelajaran tematik pelajaran terpadu topik 8, topik 3, pembelajaran 3 dan kedua kelas memiliki perbedaan yang mencolok. Ini dapat ditinjau dari pencapaian evaluasi peserta didik yang beranekaragam setelah pelatihan antara kelompok eksperimen dan kontrol. Kumpulan pengamatan dalam melaksankan metode PBL pada topik pelajaran terpadu pada topik 8 topik 3 pembelajaran 3 dan rata-rata 86,56, sedangkan kelompok kontrol menerapkan metode pembelajaran tradisional pada topik pembelajaran terpadu topik 8 topik 3 pembelajaran 3 Dan memiliki nilai mean 65 dan 61. Oleh karena itu, kesimpulannya model PBL berpengaruh signifikan pada prestasi peserta didik di kelas V SDN 35 Parak Karakah wilayah Padang Timur menggunakan pembelajaran tematik terpadu.

Hasil penelitian (Adetya and Desyandri 2019) menjelaskan bahwa perkembangan pada peserta didik dalam pelajaran tematik yang pelaksanaannya memerlukan metode pelajaran PBL. Pada evaluasi aspek RPP $(90,28 \%)$ dalam tahap I. Angka ini meningkat menjadi $9 \%$ dalam tahap II. Kemauan siswa dalam kegiatan belajar mengajar dari sisi guru dalam tahap I yaitu $85,71 \%$ berkembang menjadi $92,85 \%$ dalam tahap II dan tahap I siswa meningkat $82,1 \%$ dari $92,85 \%$ dalam tahap II. hasil dari 80 , dalam tahap pertama menjadi 85,06 pada siklus kedua. Pengamatan ini dilaksanakan di SD Negeri 03 Pakan Kurai peningkatan pada proses pelajaran kepada peserta didik dalam pengajaran tematik terpadu di kelas V SD Negeri 03 Pakan Kurai Bukittinggi yang pelaksanaannya menitikberatkan pada penggunaan metode (PBL).

Hasil pengamatan (Melindawati 2019) menjelaskan pengintegrasian model PBL ke kelas SD tahap pengembangan bahan ajar tematik merupakan topik yang penting. Dari hasil evaluasi materi oleh evaluator dan praktisi berpengalaman yang dilakukan pada RPP maupun materi yang diajarkan. Kepraktisan bahan ajar terintegrasi dengan topik 8 PBL model 8. Tempat Tinggal Saya dan Topik 1. Lingkungan Hidup Saya Dari Pengamatan Bahan Ajar, RPP Guru Guru mengklasifikasikan bahan ajar ke dalam kategori praktis I akan. Kepraktisan materi juga tercermin dari reaksi siswa yang mengikuti pembelajaran dengan materi dan reaksi guru yang menggunakan RPP dengan hasil yang sangat baik. Keefektifan materi pelajaran tematik yang mengintegrasikan metode PBL kelas IV SD tema 8. Tempat tinggal saya dan sub tema 1. Lingkungan tempat tinggal saya dikenal melalui kegiatan dan hasil belajar siswa. Aktivitas belajar siswa sangat baik, dan hasil belajar ditampilkan secara efektif. Oleh karena itu, dalam kategori sangat tepat, rata-rata RPP diverifikasi menjadi 3,7. Dalam verifikasi subjek, Anda akan mendapatkan IPK 3,7, yang merupakan standar yang sangat baik. Prestasi siswa secara keseluruhan adalah $88 \%$ hasil belajar siswa kelas SD meningkat. Artinya materi tematik yang dibangun dalam model PBL efektif, praktis dan bermanfaat.

Hasil penelitian (Rahman and Latif 2020) menjelaskan bahwa keterampilan siswa dalam memecahkan masalah pada peserta didik kelas 5 SD dengan tematik terpadu berbasis PBL meningkat. Dokumen yang disajikan mudah dilaksanakan, sangat valid. Materi pembelajaran terpadu dengan pertanyaan efektif dalam proses pembelajaran. Keterampilan peserta didik dalam memecahkan masalah pada kelas 5 SD meningkat dengan kegiatan pelajaran yang memerlukan metode berbasis masalah dalam pelajaran tematik terpadu efektif 
2177 Pembelajaran Tematik Terpadu menggunakan Model Problem Based Learning di Sekolah Dasar Firda Khairati Amris, Desyandri

DOI: https://doi.org/10.31004/basicedu.v5i4.1170

digunakan. Penelitian (Warizona 2016) menjelaskan bahwa Pelaksanaan pembelajaran tematik PBL dilakukan secara bertahap, meliputi orientasi pemecahan masalah, organisasi pembelajaran siswa, orientasi penelitian individu dan kelompok, pembangunan dan presentasi kerja, kerja, serta proses pemecahan masalah analisis dan evaluasi. Pelaksanaan metode PBL pada kegiatan belajar mengajar meningkat setiap siklusnya. Oleh karena itu, model (PBL) di SD Negeri 01 Pauh Kuraitaji, Kota Pariaman dapat ditingkatkan dalam proses pembelajaran.

Kemudian (Marsali 2016) menjelaskan bahwa pelaksanaan pembelajaran tematik terpadu meningkat setiap siklusnya dengan model PBL, mulai dari penerapan oleh guru hingga penerapan oleh siswa. Persentase guru yang menyelesaikan siklus 1 sekali adalah 78,57 ijazah penuh. Persentase pertemuan pertama pada pertemuan kedua juga tinggi yaitu 88,89, dan persentase pertemuan kedua pada pertemuan pertama adalah 92,86 , yang merupakan skor yang sangat baik. Pada ujian, siswa yang lulus ujian pertama mendapat nilai $88,89 \%$ dari ujian. Selain itu, persentase game pertama dan kedua adalah 89,29 dengan catatan baik, dan persentase game pertama di babak kedua sangat baik yaitu 92,86. Oleh karena itu, pembelajaran terpadu SD PGAI kelas IV di Kecamatan Padang Timur Kota Padang dapat dtingkatkan melalui metode PBL.

Hasil pengamatan (Saputra 2016) Menjelaskan bahwa dengan metode PBL pada pelajaran implementasi pembelajaran kemampuan memecahkan masalah secara konkrit tematik semakin meningkat dari sudut pandang guru dan siswa. Peningkatan yang muncul dari Siklus 1, 2 dan 3 adalah siswa dapat menjadi siswa yang berorientasi pada masalah, mengorganisasikannya saat belajar, dan mengajar siswa secara individu atau kelompok melalui pertanyaan. Siswa dapat mengembangkan dan mempresentasikan karyanya. Siswa dalam proses pemecahan masalah dapat menganalisis dan mengevaluasi. Evaluasi dan pencapaian belajar dalam tahap I memberikan persentase rata-rata 67,97, berkembangang menjadi 73,11, siklus II dan meningkat menjadi 77,08 siklus III. Jadi keterampilan dalam memecahkan masalah pada tematik kelas IV SDN. 03 alai kota Padang yang menggunakan metode PBL meningkat.

Hasil penelitian (Hasanah and Fitria 2021) menjelaskan model PBL mempengaruhi kognitif IPA pada "lingkungan teman", subtopik perubahan lingkungan, khususnya pada pembelajaran tematik yang terintegrasi dengan pelajaran 1, 2 serta 5. Ini telah terbukti. Dari hasil yang diperoleh diketahui rata-rata dalam pengamatan yaitu 78,22 dan rata-rata dalam bimbingan yaitu 68, 1. Pengetahuan meningkat dalam pengamatan menghasilkan mean gain yaang sangat bagus pada kelas bimbingan adalah 0,51 dan 0,31 . Dalam hal ini, kemampuan kognitif IPA dalam pembelajaran mata pelajaran terpadu penggunaan model pembelajaran berbasis masalah ternyata berpengaruh. Kemudian (Hastuti and Zaiyasni 2020) menjelaskan bahwa peningkatan pelaksanaan rencana pembelajaran, pelaksanaan hasil belajar, dan kinerja pembelajaran terpadu berbasis mata pelajaran yang memerlukan metode (PBL). Ini ditunjukkan melalui peningkatan secara periodik. Oleh karena itu, Pencapian evaluasi pelajaran yang memerlukan metode PBL dalam pelajaran terpadu kelas V SDN 17 Koto Tangah meningkat.

Hasil pengamatan (Febriani 2020) menjelaskan pelaksanaan proses pembelajaran tematik terpadu dalam tahap I ke tahap II yang pelaksanaannya memnggunakan meide PBL meningkat. Rerata observasi RPP dalam tahap I adalah 8,72 , dengan pencapaian hasil belajar yaitu 9\% dalam tahap II dan titer sudah bagus dengan persentase kenaikan yaitu 99,72\%. Hasil observasi praktik belajar mengajar bahwa rata-rata pendidik dalam tahap I sebesar 82,21, kelas mengalami kenaikan yaitu 92,85\% dalam tahap II, nilai bagus atau di atas angka tersebut meningkat sebesar 10,6 \%. Pengamatan siswa dalam tahap I menunjukkan rata-rata 82,21 dengan nilai bagus naik dari 10,6\% menjadi 92,85\% dalam tahap II. Model PBL dalam Tema Kelas V SD Negeri 12 Gunung Tulleh dapat meningkatkan proses pembelajaran tematik.

Hasil penelitian (Novianti, Bentri, and Zikri 2020) menjelaskan bahwa kegiatan serta keingin peserta didik dalam ikut serta pada pelaksanaan pelajaran terpadu tematik kelas $\mathrm{V}$ terhadap pengaruh metode pembelajaran berbasis masalah. Diperoleh adanya dampat dalam pelaksanaan menggunakan metode pembelajaran PBL pada kegiatan belajar peserta didik berlandasan perhitungan uji-t. Hasil signifikansinya 
2178 Pembelajaran Tematik Terpadu menggunakan Model Problem Based Learning di Sekolah Dasar Firda Khairati Amris, Desyandri

DOI: https://doi.org/10.31004/basicedu.v5i4.1170

sebesar 0,00 yang berada di bawah taraf signifikansi 0,05 dari hasil uji hipotesisnya. Kemampuan peserta didik dalam mengikuti proses belajar mengajar berbasis perhitungan uji-T, dengan taraf signifikansi 0,00 , dikategorikan rendah dari tingkat signifikansi 0,05 untuk pelajaran pada mata pelajaran terpadu kelas $\mathrm{V}$ yang berdampak pada metode pelajaran PBL. Oleh karena itu, kegiatan serta pemerolehan prestasi peserta didik di kelas V SD dengan pelaksanaan model pelajaran pemecahan masalah (PBL) dapat meningkat.

Hasil penelitian (Vera and Astuti 2019) menjelaskan bahwa produktivitas serta dan prestasi peserta didik kelas V SDN Sidorejo Lor 05 Salatiga dengan model pembelajaran PBL meningkat. Produktivitas serta pencapaian prestasi peserta didik kelas V semakin hari semakin berkembang. Bisa dilihat pada Prasiklus, tahap 1 maupun tahap 2 Sebelumnya cuma 2 dari 35 peserta didik yang mendapatkan nilai pas KKM. Dalam tahap 1 cuma 27 dari 35 peserta didik yang menerima KKM. Pada tahap 1 maupun tahap 2. mengalami perkembangan. Dengan kata lain, ada 30 siswa dengan nilai KKM tertinggi. Demikian pula dengan data prestasi akademik siswa kelas $\mathrm{V}$ sebelum siklus yang hanya melibatkan 8 peserta didik yang memperoleh nilai pas KKM dari 35 peserta didik. Dalam tahap 1, 19 peserta didik mencapai KKM lebih tinggi. Dalam tahap II cuma 33 peserta didik yang mencapai KKM di atas.

Penelitian (Rahayu 2016) menjelaskan bahwa sikap dan hasil belajar kolaboratif siswa, umpan balik peserta didik, yang memerlukan metode pelajaran berbasis masalah pada kegiatan belajar peserta didik, proses pelaksanaan kegiatan belajar mengajar menggunakan metode pelajaran berbasis masalah pada masalah, pencapaian prestasi belajar kolaboratif peserta didik yang dapat meningkatkan sikap siswa. Terlihat adanya setiap siklusnya peningkatan. Jadi perilaku serta pencapaian prestasi peserta didik dalam pelajaran tematik 1 sifat budaya masyarakat SDN Kenkan Inder 2 pada tahun keempat. keindahan satu. Kecamatan Rancaekek, Kabupaten Bandung pada pelaksanaan metode pelajaran berbasis masalah mengalami perkembangan.

Berdasarkan analisis serta pembahasan dalam artikel sebelumnya, model PBL efektif dalam menerapkan pembelajaran berbasis mata pelajaran terpadu di sekolah dasar. Tahapan model PBL yang mendorong partisipasi aktif siswa dalam pembelajaran disediakan dengan menyajikan masalah, sehingga siswa mengatur pengetahuannya untuk keberhasilan implementasi penerapan model pembelajaran tematik terpadu.

\section{KESIMPULAN}

Berdasarkan hasil analisis di atas, diperkuat dengan berbagai komentar dan teori, penerapan model PBL efektif diterapkan pada pembelajaran terpadu berbasis mata pelajaran pada intansi pendidikan terutama sekolah dasar. Penerapan metode pelajaran berbasis masalah memaksa peserta didik untuk melakukan pembelajaran sendiri dan menggali informasi siswa untuk secara aktif, untuk menyajikan masalah dan mengembangkan pengetahuan mereka sendiri.

\section{SARAN}

Berdasarkan hasil analisis artikel di atas, penulis telah membangun model PBL, yaitu pembelajaran terpadu sebagai rencana pembelajaran yang sesuai dan penerapan model pembelajaran berbasis masalah buatan guru saran saat memilih model pembelajarannya.

\section{DAFTAR PUSTAKA}

Adetya, Oklin, And Desyandri Desyandri. 2019. "Peningkatan Hasil Belajar Tematik Terpadu Menggunakan Model P Roblem Based Learning ( PBL ) Di Sekolah Dasar Improvement Of Integrated Thematic Learning Outcomes Using The Problem Based Learning ( Pbl ) Model In Elementary School.” 7. 
2179 Pembelajaran Tematik Terpadu menggunakan Model Problem Based Learning di Sekolah Dasar Firda Khairati Amris, Desyandri

DOI: https://doi.org/10.31004/basicedu.v5i4.1170

Desyandri, Dori, And Vernanda. 2017. "Pengembangan Bahan Ajar Tematik Terpadu Di Kelas V Sekolah Dasar Menggunakan Identifikasi Masalah.” Seminar Nasional HDPGSDI Wilayah 4: 163-74. Https://Ejournal.Unpatti.Ac.Id/Ppr_Paperinfo_Lnk.Php?Id=1720.

Desyandri, Muhammadi, Mansurdin, And Rijal Fahmi. 2019. "Development Of Integrated Thematic Teaching Material Used Discovery Learning Model In Grade V Elementary School." Jurnal Konseling Dan Pendidikan 7(1): 16.

Dewi, Tanti Agviola, And Naniek Sulistya Wardani. 2019. "Peningkatan Hasil Belajar Tematik Melalui Pendekatan Problem Based Learning Siswa Kelas 2 SD." Jurnal Riset Teknologi Dan Inovasi Pendidikan 2(1): 234-42.

Efendi, Dwi Ratna, And Krisma Widi Wardani. 2021. "Komparasi Model Pembelajaran Problem Based Learning Dan Inquiry Learning Ditinjau Dari Keterampilan Berfikir Kritis Siswa Pada Mata Pelajaran IPA Di Sekolah Dasar.” Jurnal Basicedu 5(3): 1277-85.

Eliyasni, Rifda, Yesi Anita, And Andre Satrio Hanafi. 2020. "Proses Pembelajaran Tematik Terpadu Dengan Model Problem Based Learning Di Sekolah Dasar." 5(2).

Febriani, Rahmatina. 2020. "Peningkatan Proses Pembelajaran Tematik Terpadu Dengan Menggunakan Model Problem Based Learning Di Kelas V Sekolah Dasar.” 4: 2354-59.

Handayani, R H, And M Muhammadi. 2020. "Pengaruh Model Pembelajaran Problem Based Learning Terhadap Hasil Belajar Siswa Dalam Pembelajaran Tematik Terpadu Di Kelas V SD.” E-Journal $\begin{array}{lllll}\text { Pembelajaran } & \text { Inovasi } & \ldots & 8: & 78-88 .\end{array}$ Http://Ejournal.Unp.Ac.Id/Students/Index.Php/Pgsd/Article/View/9780.

Hasanah, Mutiara, And Yanti Fitria. 2021. "Pengaruh Model Problem Based Learning Terhadap Kemampuan Kognitif IPA Pada Pembelajaran Tematik Terpadu.”Jurnal Basicedu 5(3): 1509-17.

Hastuti, Hendriani Zora, And Zaiyasni. 2020. "Peningkatan Hasil Belajar Siswa Menggunakan Model Problem Based Learning Pada Pembelajaran Tematik Terpadu." Jurnal Pendidikan Tambusai 4(3): 2731-40.

Indriyani. 2019. “Perbedaan Model Children'S Learning In Science (Clis) Dan Model Scientific Terhadap Hasil Belajar Siswa Pada Pembelajaran Tematik Terpadu Di Sekolah Dasar." Jurnal Basicedu 2(1): 627-33.

Julia Purnama Sari; Yunisrul; Desyandri. 2018. "Peningkatan Pembelajaran Tematik Dengan Pendekatan Scaintifik Di Kelas I SDN 15 Ulu Gadut, Kota Padang.” Ejournal Pembelajaran Inovasi: Jurnal Ilmiah Pendidikan Dasar 6(1): 11-24. Http://Ejournal.Unp.Ac.Id/Students/Index.Php/Pgsd/Article/View/3906/2485.

Krismayanti, Widya. 2020. "Proses Pembelajaran Tematik Terpadu Dengan Model Problem Based Learning ( PBL ) Di Sekolah Dasar." 8: 102-10.

Kristin, Firosalia. 2018. "Peningkatan Kerjasama Dan Hasil Belajar Tematik Melalui Model Pembelajaran Problem Based Learning.” Kajian Penelitan Pendidikan Dan Pembelajaran 3(1): 254-68.

Maharani, Bekti Yuni, And Agustina Tyas Asri Hardini. 2017. "Penerapan Model Pembelajaran Discovery Learning Berbantuan Benda Konkret Untuk Meningkatkan Hasil Belajar Ipa." E-Jurnalmitrapendidikan 1(5): 549-61.

Majid, Abdul. 2014. "Pembelajaran Tematik Terpadu."

Marsali, Annisa. 2016. "Peningkatan Pembelajaran Tematik Terpadu Dengan Menggunakan Model Problem Based Learning Di Kelas Iv Sekolah Dasar." E-Jurnal Inovasi Pembelajaran SD 1: 1-17. Http://Www.Elsevier.Com/Locate/Scp.

Melindawati, Silfi. 2019. "Pengembangan Bahan Ajar Tematik Terpadu Dengan Model Problem Based Learning Di Kelas IV SD.” Journal Of Chemical Information And Modeling 53(9): 1689-99. 
2180 Pembelajaran Tematik Terpadu menggunakan Model Problem Based Learning di Sekolah Dasar Firda Khairati Amris, Desyandri

DOI: https://doi.org/10.31004/basicedu.v5i4.1170

Mesyta Putri Ayu, Taufina Taufik. 2020. "Penerapan Strategi Pembelajaran Inkuiri Dalam Pembelajaran Tematik.” 8(8): 421-32. Http://Ejournal.Unp.Ac.Id/Students/Index.Php/Pgsd.

Novianti, Ade, Alwen Bentri, And Ahmad Zikri. 2020. "Pengaruh Penerapan Model Problem Based Learning

(Pbl) Terhadap Aktivitas Dan Hasil Belajar Siswa Pada Pembelajaran Tematik Terpadu Di Sekolah

Dasar." Jurnal Basicedu 4(1): 194-202.

Prananda, Gingga. 2020. "Pengembngan Media Video Pembelajaran Tema 6 Subtema 2 Untuk Siswa Kelas SD Negeri 17 Pasar Masurai 1.” Jurnal Dharma PGSD 1(1): 38-45.

Rahayu, Irna. 2016. "Penerapan Model Pembelajaran Problem Based Learning Untuk Meningkatkan Sikap Kerja Sama Dan Hasil Belajar Siswa Pada Pembelajaran Tematik Di Sdn Kencana Indah Ii.” Pendidikan Guru Sekolah Dasar Http://Www.Tjyybjb.Ac.Cn/CN/Article/Downloadarticlefile.Do?Attachtype=PDF\&Id=9987.

Rahman, Mardia Hi, And Saiful Latif. 2020. "Pengembangan Bahan Ajar Tematik Terpadu Berbasis Problem Based Learning Untuk Meningkatkan Kemampuan Berpikir Kritis Siswa SD Kelas V.” Edukasi 18(2): $246-58$.

Ramadani, Uci Tri, And Mansurdin. 2020. "Peningkatan Proses Pembelajaran Tematik Terpadu Menggunakan Model Problem Based Learning Di Kelas IV." E-Journal Pembelajaran Inovasi, Jurnal Ilmiah Pendidikan Dasar 8(C): 52-66. Http://Ejournal.Unp.Ac.Id/Students/Index.Php/Pgsd.

Ramadhani. 2021. "Studi Literatur Pembelajaran Problem Based Learning ( PBL ) Dalam Pembelajaran Tematik.": 213-19.

Reinita. 2020. "Peningkatan Hasil Belajar Tematik Terpadu Dengan Model Problem Based Learning Di Sekolah Dasar." Journal Of Moral And Civic Education 4(2): 2549-8851.

Saputra, ARIEF TRIHANDOKO. 2016. "Peningkatan Kemampuan Berpikir Kritis Menggunakan Model Problem Based Learning (Pbl) Pada Pembelajaran Tematik Terpadu Di Sekolah Dasar." E-Journal Pembelajaran Inovasi, Jurnal Ilmiah Pendidikan Dasar 1(1): 1-16. Http://Ejournal.Unp.Ac.Id/Students/Index.Php/Pgsd/Article/View/2008.

Setiyaningrum, Monika. 2018. "Peningkatan Hasil Belajar Menggunakan Model Problem Based Learning (PBL) Pada Siswa Kelas 5 SD N.” Jartika 1(2): 99-108.

Trianto. 2009. "Mendesain Model Pembelajaran Inovatif-Progresif Dan Implementasinya Pada Kurikulum Tingkat Satuan Pendidikan (KTSP)." Jakarta: Prenada Media Group: 242.

Vera, Monika, And Suhandi Astuti. 2019. "Peningkatan Kreativitas Dan Hasil Belajar Siswa Melalui Model Pembelajaran Problem Based Learning Pada Kelas Vsdn Sidorejo Lor V Salatiga." Monika Vera Mawardi Suhandi Astuti 6(1): 11-21.

Warizona, D O. 2016. "Peningkatan Pembelajaran Tematik Terpadu Dengan Model Problem Based Learning (Pbl) Di Kelas Iv Sd.” E-Journal Pembelajaran Inovasi, Jurnal Ilmiah ...: 2-16.

Wulandari, Taufina. 2020. "Penerapan Model Problem Based Learning (PBL) Dalam Pembelajaran Tematik Terpadu Di Kelas V Sekolah Dasar." ... Pembelajaran Inovasi, Jurnal Ilmiah ... 8. Http://Ejournal.Unp.Ac.Id/Students/Index.Php/Pgsd/Article/View/9057.

Yelnosia, Rahma, And Taufina Taufik. 2020. "Penerapan Model Problem Based Learning Dalam Pembelajaran Tematik Terpadu Di Kelas V Sekolah Dasar Application Of The Problem Based Learning Model In Integrated Thematic Learning For Grade V Of Elementary Schools." 8.

Yolanda, Yona. 2018. "Pembelajaran Tematik Terpadu Menggunakan Model Problem Based Learning (PBL) Di Sekolah Dasar." Pembelajaran Tematik Terpadu Menggunakan Model Problem Based Learning (PBL) Di Sekolah Dasar 16(2): 29-39. 